\title{
Efficient in vivo knock-down of estrogen receptor alpha: application of recombinant adenovirus vectors for delivery of short hairpin
} RNA

\author{
Yvonne D Krom*1, Frits J Fallaux ${ }^{1,2}$, Ivo Que ${ }^{3}$, Clemens Lowik ${ }^{3}$ and \\ Ko Willems van Dijk ${ }^{1,4}$
}

\author{
Address: ${ }^{1}$ Department of Human Genetics, Leiden University Medical Center, The Netherlands, ${ }^{2}$ Netherlands Institute for Brain research, \\ Amsterdam, The Netherlands, ${ }^{3}$ Department of Endocrinology and Metabolism, Leiden University Medical Center, The Netherlands and \\ ${ }^{4}$ Department of General Internal Medicine, Leiden University Medical Center, The Netherlands \\ Email: Yvonne D Krom* - y.d.krom@lumc.nl; Frits J Fallaux - f.fallaux@nih.knaw.nl; Ivo Que - I.Que@lumc.nl; \\ Clemens Lowik - C.W.G.M.Lowik@lumc.nl; Ko Willems van Dijk - K.Willems_van_Dijk@lumc.nl \\ * Corresponding author
}

Published: 28 February 2006

BMC Biotechnology 2006, 6:1I doi:10.1 I86/1472-6750-6-1।

This article is available from: http://www.biomedcentral.com/l472-6750/6/II

(c) 2006 Krom et al; licensee BioMed Central Ltd.

This is an Open Access article distributed under the terms of the Creative Commons Attribution License (http://creativecommons.org/licenses/by/2.0), which permits unrestricted use, distribution, and reproduction in any medium, provided the original work is properly cited.

\begin{abstract}
Background: Adenovirus (Ad) mediated gene transfer is a well-established tool to transiently express constructs in livers of mice in vivo. In the present study, we determined the specificity and efficiency of Ad vectors expressing short hairpin (sh) RNA constructs to knock-down the estrogen receptor $\alpha(E R \alpha)$.

Results: Two different shRNA constructs derived from the murine ER $\alpha$ coding sequence were designed $(\operatorname{shER} \alpha)$. In vitro, transfection of three mouse cell lines with PSUPER-shER $\alpha$ constructs resulted in up to $80 \%$ reduction of endogenous $E R \alpha$ activity. A single mismatch in the target sequence eliminated the reduction of ER $\alpha$ activity, demonstrating the specificity of shER $\alpha$. The subsequently generated Ad.shER $\alpha$ vectors were equally effective in vitro. In vivo, intravenous administration of Ad.shER $\alpha$ resulted in $70 \%$ reduced hepatic mouse ER $\alpha$ mRNA levels. Coinjection of Ad.shER $\alpha$ with an Ad vector containing a luciferase (luc) gene driven by an estrogen responsive element (ERE) containing promoter resulted in a significant ( $90 \%$ on day five) downregulation of hepatic luciferase activity, as determined by non-invasive optical imaging. Downregulation was sustained up to day seven post-injection.
\end{abstract}

Conclusion: Ad mediated transfer of shER $\alpha$ expression constructs results in efficient and specific knockdown of endogenous $\mathrm{ER} \alpha$ transcription both in vitro and in vivo.

\section{Background}

Estrogen exerts various biological effects in numerous organs throughout the body and has been implicated in the pathophysiology of a number of diseases including breast cancer, osteoporosis and cardiovascular disorders. Most of the estrogenic effects are mediated via the two known estrogen receptors, ER $\alpha$ and ER $\beta$. These estrogen receptors are ligand-dependent transcription factors that can modulate gene transcription directly but also indirectly. Thus far, there is a relative paucity in the description of the role of estrogen and estrogen receptors in specific organs. Most studies have been performed using 
$\mathbf{A}$

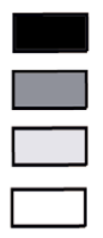

Empty

shER $\alpha \_1395$

shER $\alpha \_1103$

shER $\alpha \_T a n d e m$

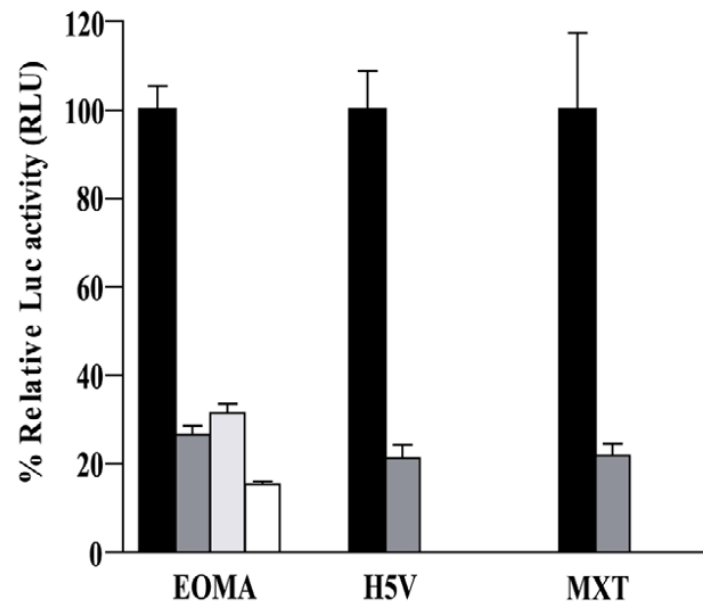

C

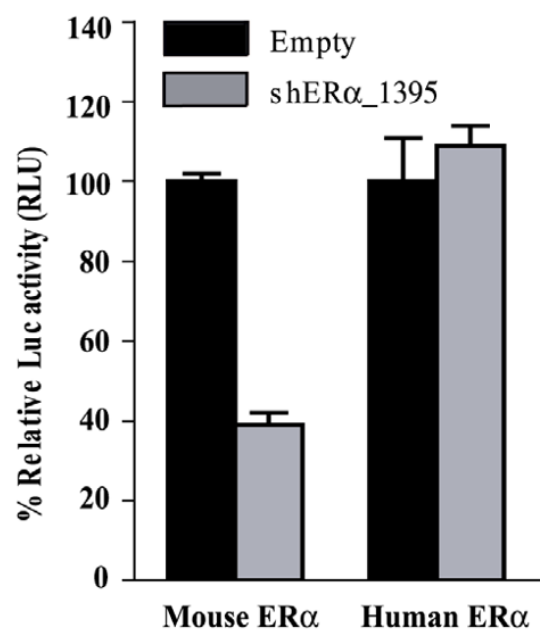

B

mER $\alpha$ AAGCTCCTGTTTGCTCCTAACTT

hER $\alpha$ AAGCTACTGTTTGCTCCTAACTT mER $\beta$ AAGCTCATCTTTGCTCCAGACCT

\section{Figure I}

Affectivity and specificity of pSUPER mediated expression of shER $\alpha$ in mouse cell lines. $(A+C)$ The indicated mouse cell lines were co-transfected with, ERE-Luc, CMV-LacZ, and pSUPER-empty, PSUPER-shER $\alpha$ I395, pSUPERshER $\alpha \_$II 03, or PSUPER- shER $\alpha \_$tandem. Subsequently, the cells were treated 24 hours with 10-9 M I7- $\beta$-estradiol. Luciferase activity was measured 48 hours after transfection and after correction for LacZ expression, represented as the mean $(n=3) \pm$ $S D$ relative to the transfection with PSUPER-empty. (A) Endogenous mouse ER $\alpha$ mediated transcription in EOMA, H5V and MXT cells after introducing PSUPER +/- shER $\alpha$. (B) The 19-nt target-recognition sequence of ER $\alpha$ _I395 contains one mismatch with human $E R \alpha$ and five mismatches with the mouse ER $\beta$ sequence. (C) ER $\alpha$ mediated transcription in EOMA cells after over expression of either mouse ER $\alpha$ - or human ER $\alpha$-expression vectors in presence of PSUPER empty or pSUPER shER $\alpha$ I 395 (D) Western blot analysis of H5V cells co-transfected with PCMV-mER $\alpha$ and pSUPER-empty or pSUPERshER $\alpha \_$_ 395. The lysates were analysed by immunoblotting (insert-photo) with anti-mouse ER $\alpha$ and anti-p38. The intensity of the bands was quantified and normalized to cells transfected with PSUPER-empty. The relative ER $\alpha$ protein levels are presented (bar-diagram) as mean $(n=3)+/$ - SD. 
non-tissue specific manipulation of ER signaling such as complete knockouts either via deletion of the estrogen receptor or via deletion of estrogen production by ovariectomy. The availability of tools to specifically address the role of ER signaling in individual tissues would thus fill a void.

Short synthetic duplexes of 21 nucleotides long RNA molecules can specifically inhibit gene expression in mammalian cells [1]. Because of their efficacy and specificity, siRNA molecules provide a powerful tool to dissect gene function. To expand the applicability of the siRNA approach, Brummelkamp and co-workers [2] have introduced vector-based siRNA expression systems. By directing the synthesis of shRNA via the polymerase-III H1 RNA gene promoter, effective siRNA molecules are formed intracellular after transfection of shRNA expression constructs. To further expand the applicability of the siRNA approach, recombinant retro- and adenoviral based vectors have been designed $[3,4]$. Of these, adenoviral vectors offer the advantage of highly efficient infection of a broad range of cells, independent of active cell division. Moreover, high titers can be obtained and intravenous injection results in efficient transduction of the liver.

The present study was designed to generate tools to address the role of ER $\alpha$ in a tissue- and time- specific manner. To this end, we have developed recombinant Ad vectors encoding shRNA's directed against mouse ER $\alpha$ (Ad.shER $\alpha$ ). Introduction of shER $\alpha$, either by transfection or by Ad mediated gene transfer into different murine cell lines, led to efficient sequence specific repression of ER mediated transcription. Furthermore, intravenously administration of Ad.shER $\alpha$ resulted in efficient reduction of hepatic $E R \alpha$ mRNA levels $(P<0.005)$ and $E R \alpha$ functionality.

\section{Results}

Efficient and specific knock-down of endogenous $m E R \alpha$ in vitro: Transfection with pSUPER-shER $\alpha$ constructs

Three pSUPER-derived vectors [2] designed to drive expression shER $\alpha$ sequences were constructed. Two vectors contained sh sequences derived from the boundary of the DNA binding domain and the hinge region (shER $\left.\alpha \_1103\right)$, or from the ligand binding domain (shER $\left.\alpha \_1395\right)$ of $m E R \alpha$, respectively. A third expression vector contained both the shER $\alpha \_1103$ and shER $\alpha \_1395$ expression cassettes in series (shER $\alpha \_$tandem).

The efficiency of the shER $\alpha$ constructs for reducing endogenous ER $\alpha$ activity in vitro was determined using a luciferase reporter assay. For this purpose, the pSUPERshER $\alpha$ 1395, pSUPER-shER $\alpha$ 1103, or PSUPERshER $\alpha \_$tandem were transfected together with a reporter plasmid carrying a trimer of ERE plus TATA box upstream of luciferase (pERE-Luc) into endothelial cell lines (EOMA and H5V) and in mouse breast cancer cells (MXT). As shown in Figure 1A, upon transfection with shERo_1395, relative luciferase activity in lysates of all three cell lines was reduced by $70-80 \%$. A similar result was obtained with shER $\alpha \_1103$ in EOMA's. In addition, the shERa_tandem expression construct proved to be more efficient than either of single shER $\alpha$ contructs alone in the EOMA cells, adding some $15 \%$ to the $70 \%$ reduction observed with shERa_1395 (Fig. 1A).

To evaluate the specificity of the shER $\alpha$ construct, shERa_1395 was introduced into EOMA cells overexpressing either mouse ER $\alpha$ or human ER $\alpha$. The ER $\alpha \_1395$ target sequence contains only a single mismatch with the human ER $\alpha$ (Fig. 1B). Significant suppression of ER $\alpha$ mediated transcription was only observed in lysates of cells that were transfected with mouse ER $\alpha$ but not with human ER $\alpha$ (Fig. 1C). Thus, the observed effects of shERa_1395 are specific for mouse ER $\alpha$. Moreover, changing a single nucleotide in shER $\alpha \_1395$ completely abolished the silencing effect (data not shown). By western blotting, the effect of shER $\alpha$ on ER $\alpha$ protein expression was studied (Fig. 1D). In the presence of shER $\alpha \_1395$, ER $\alpha$ protein levels were reduced to $33 \%$ as compared to control transfected cells. This reduction correlated well with our findings in the luciferase reporter assay. Thus, the observed inhibition of luciferase activity upon treatment with shER $\alpha \_1395$ or shER $\alpha \_1103$ is caused by reduced accumulation of $\mathrm{mER} \alpha$ protein. All together, the shER $\alpha \_1395$ and shER $\alpha \_1103$ expression vectors are effective and specific in repression of murine ER $\alpha$ expression.

\section{Knock-down of hepatic $E R \alpha$ expression in vivo: using Ad.shER $\alpha$ vectors}

To repress ER $\alpha$ activity in vivo, Ad vectors expressing either shERo_1395 (Ad.shERo_1395), shERa_1103 (Ad.shER $\alpha \_1103$ ) or both (Ad.shER $\left.\alpha \_t a n d e m\right)$ were generated (Fig. 2A). The H1 RNA promoter plus shER $\alpha$ expression cassettes were sub-cloned from the corresponding pSUPER into pAdTrack [5], which is engineered to co-express GFP enabling the tracking of infected cells. In addition, we constructed a control AdTrack plasmid, carrying only the H1 RNA promoter, which allowed for the generation of Ad.Empty. Prior to the evaluation of recombinant Ad vectors in vivo, we tested the functionality of the vectors in vitro. EOMA and MXT cells were transfected with pERE-luc, and subsequently infected with Ad.Empty or the Ad.shER $\alpha$ vectors. Fluorescence analysis indicated a near $100 \%$ infection percentage. The luciferase experiments (Fig. 2B) were comparable to those obtained with transfection of the pSUPER constructs (Fig. 1A): both Ad.shER $\alpha$ vectors repressed luciferase reporter activity up 
A

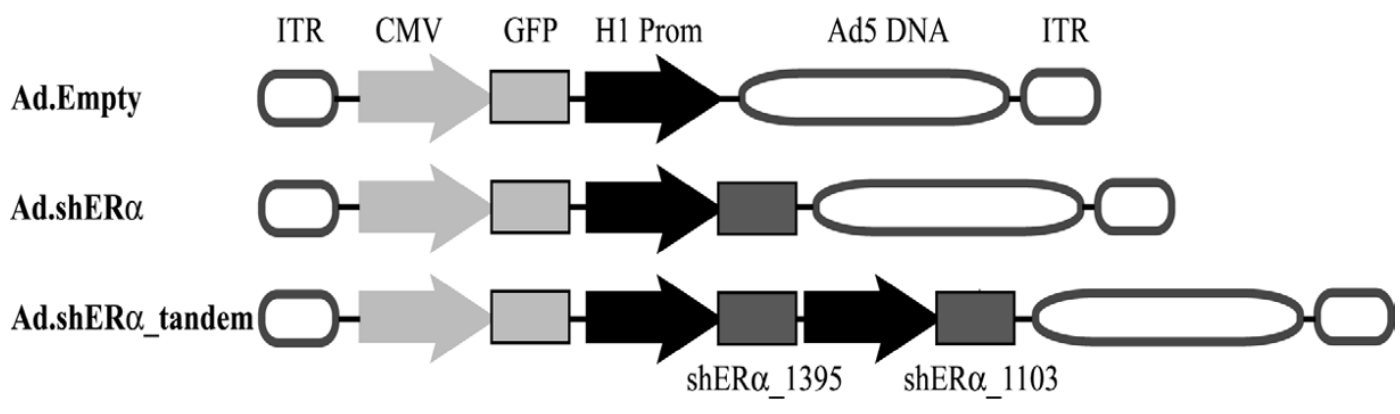

B

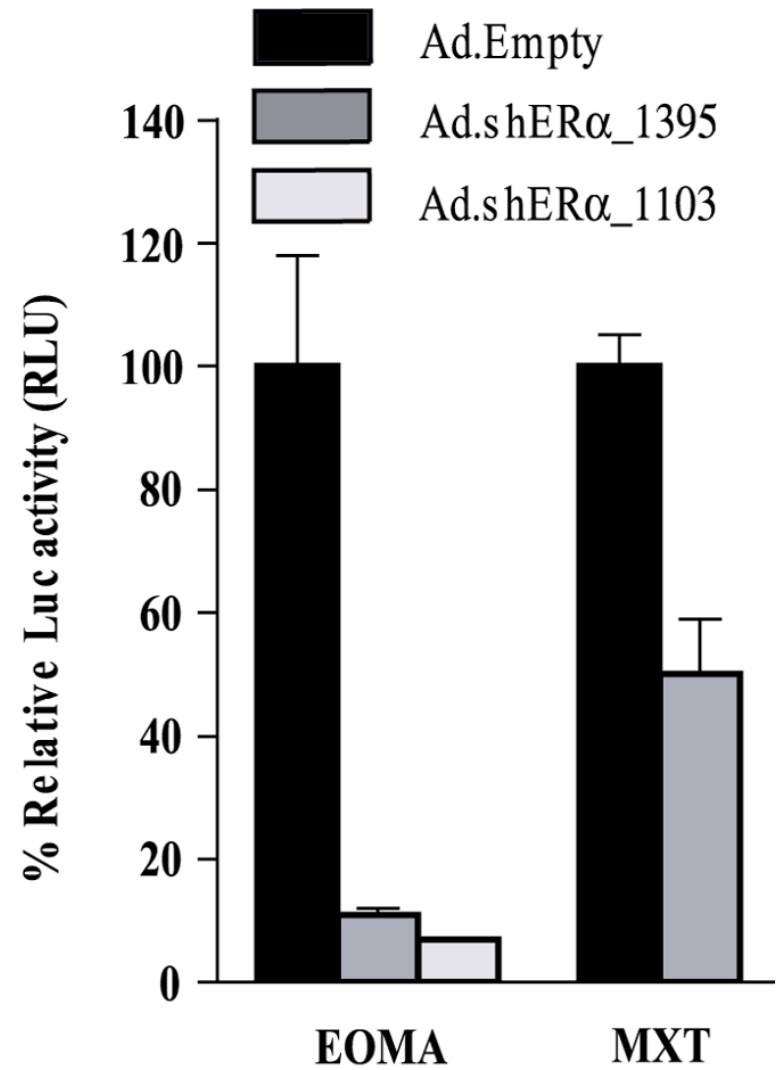

Figure 2

ER-mediated luciferase activity after Ad-mediated transfer of shER $\alpha$ in vitro. (A) Schematic representation of the recombinant Ad vectors, carrying GFP and shER $\alpha$ expression cassettes that were used in this study. (B) EOMA and MXT cells were co-transfected with pERE-Luc and PCMV-LacZ and than infected either with Ad.Empty, Ad.shER $\alpha$ _I395, or

Ad.shER $\alpha$ II 03. 10-9 M Estrogen was administrated for 24 hours. Luciferase activity was measured 48 hours after infection. Data represented as mean \pm SD relative to infection with Ad.Empty. 


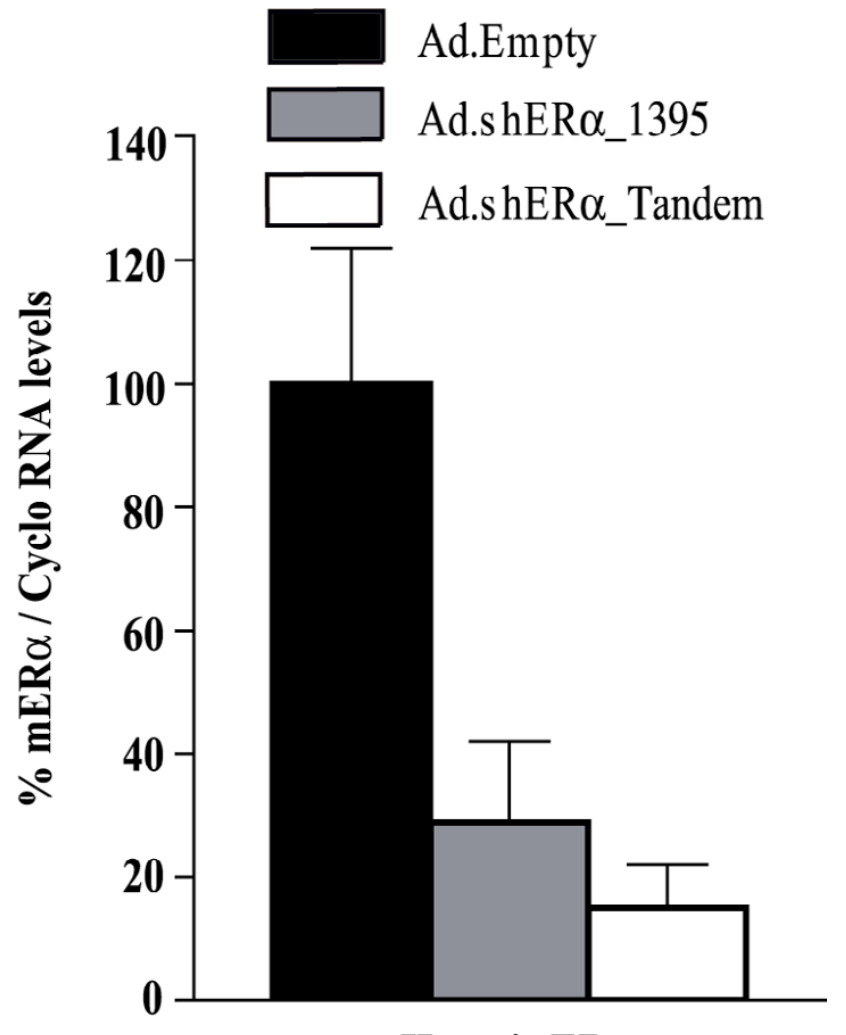

Hepatic ER $\alpha$

Figure 3

Hepatic ER $\alpha$ mRNA levels after Ad-mediated transfer of shER $\alpha$ in vivo. Male C57BI/6 mice $(n=5)$ were injected with $4 \times 10^{9}$ pfu Ad.Empty, Ad.shER $\alpha \_1395$ or Ad.shER $\alpha$ tandem. Livers were harvested Four days after Ad. administration and subjected to taqman analysis. The cyclophillin gene was used as internal standard. Data represented as mean \pm SD.

to $90 \%$. Thus, Ad.shER $\alpha$ vectors were found to be fully functional with respect to repression of $\mathrm{mER} \alpha$ activity.

We then proceeded with the application of our vectors in vivo. The Ad vectors (Ad.Empty, Ad.shERa_1395, or Ad.shER $\alpha \_$tandem) were injected in the tail vain of $\mathrm{C} 57 \mathrm{Bl} / 6$ mice. This allowed examination of inhibition by shER $\alpha$ of endogenous hepatic mER $\alpha$. Four days postinjection, animals were sacrificed, and the livers were studied for GFP expression and ER $\alpha$ mRNA level. Similar GFP expression patterns were observed in all groups, indicating equally efficient transduction (data not shown). $\mathrm{ER} \alpha \mathrm{mRNA}$ levels were studied by real time PCR analysis (Fig. 3). Administration of Ad.shER $\alpha \_1395$ reduced ER $\alpha$ mRNA levels $70 \%$, whereas hepatic expression of shERa_tandem resulted in an $85 \%$ reduction.
Subsequently, we sought to examine the extent of shER $\alpha$ mediated repression of hepatic mER $\alpha$ transcription activity. For this purpose, we constructed an Ad vector carrying the estrogen responsive luciferase reporter gene (Ad.ERELuc). First the estrogen-responsiveness of this vector was determined in vivo (Fig. 4A). Five days post-injection of 8 $\times 10^{8}$ pfu Ad.ERE-Luc, the mice were injected s.c with increasing concentrations of estrogen, ranging from 0 to $50 \mu \mathrm{g} / \mathrm{kg}$. As shown in Fig 6, 6 hours post-injection, estrogen induced hepatic luciferase activity in a dose-dependent manner. Maximal stimulation was reached after applying $25 \mu \mathrm{g} / \mathrm{kg}$ estrogen. Then, we determined to what extend Ad.shER $\alpha$ down-regulates the transcriptional activity of hepatic ER $\alpha$. Ad.shER $\alpha$ together with Ad.ERE-Luc reporter vector was administrated intravenously to C57BI/ 6 mice. Luciferase expression was detected by a CCD camera in living mice. Without estrogen treatment, all mice exhibited the same basal expression of the reporter construct (data not shown). Administration of $5 \mu \mathrm{g} / \mathrm{kg}$ estrogen, three and seven days after transduction with Ad.shER $\alpha \_1103$, resulted in a significant repression of hepatic ER $\alpha$-mediated luciferase activity (Fig. 4B). These data were confirmed by measuring luciferase activity in liver extracts of mice that received estrogen $(5 \mu \mathrm{g} / \mathrm{kg}$, sc) five days post-injection with Ad.ERE-Luc plus Ad.Empty or Ad.shERa_1103 (Fig. 4C).

We conclude that Ad-mediated introduction of shER $\alpha$ in vivo results in an almost complete repression of hepatic mER $\alpha$ mRNA levels, as well as mER $\alpha$-mediated transcription activity.

\section{Discussion}

In this paper, we demonstrate that efficient silencing of mouse ER $\alpha$ can be achieved in vitro as well as in vivo by use of Ad-mediated transfer of shRNA molecules that target the ER $\alpha$ mRNA. Two independent shER $\alpha$ plasmid and Ad vector expression constructs were generated and shown to be effective in repressing endogenous $\mathrm{ER} \alpha$ activity up to $80 \%$ in several different cell lines and in vivo (Fig. 1A, 2B and 3). In addition, a construct was made expressing both shER $\alpha$ sequences simultaneously. In vitro as well as in vivo, this construct was shown to be more effective (Fig. 1A and 3) than either of the two shER $\alpha$ constructs alone. Noninvasive optical imaging of living mice, allowed us to quantify shER $\alpha$ activity in vivo. Significant reduction of mouse ER $\alpha$ transcription levels were observed up to seven days post-transduction (Fig. 4B).

Thus far, bystander effects caused by shRNA constructs targeted to an unrelated gene have not been reported, and the specificity of the shER $\alpha \_1395$ construct was verified by the observation that human $\mathrm{ER} \alpha$, which has a single mismatch with the murine ER $\alpha$ target sequence, is not down-regulated (Fig. 1C). The number of mismatches 
A

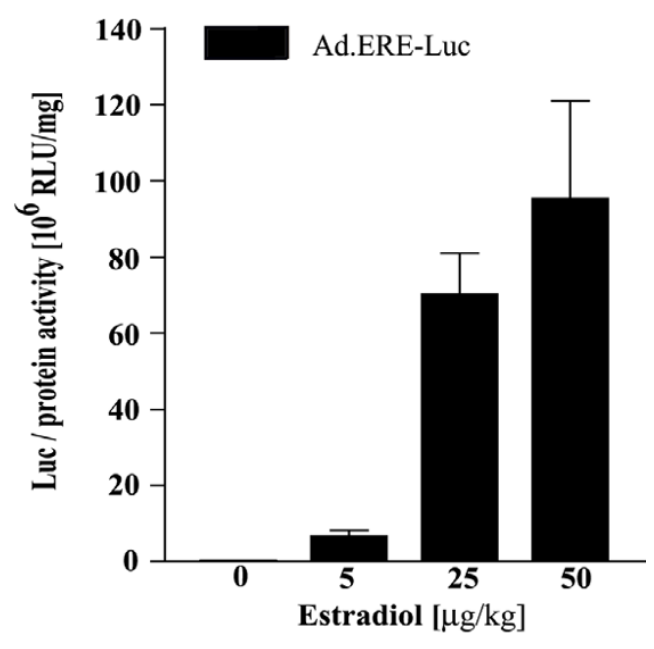

B
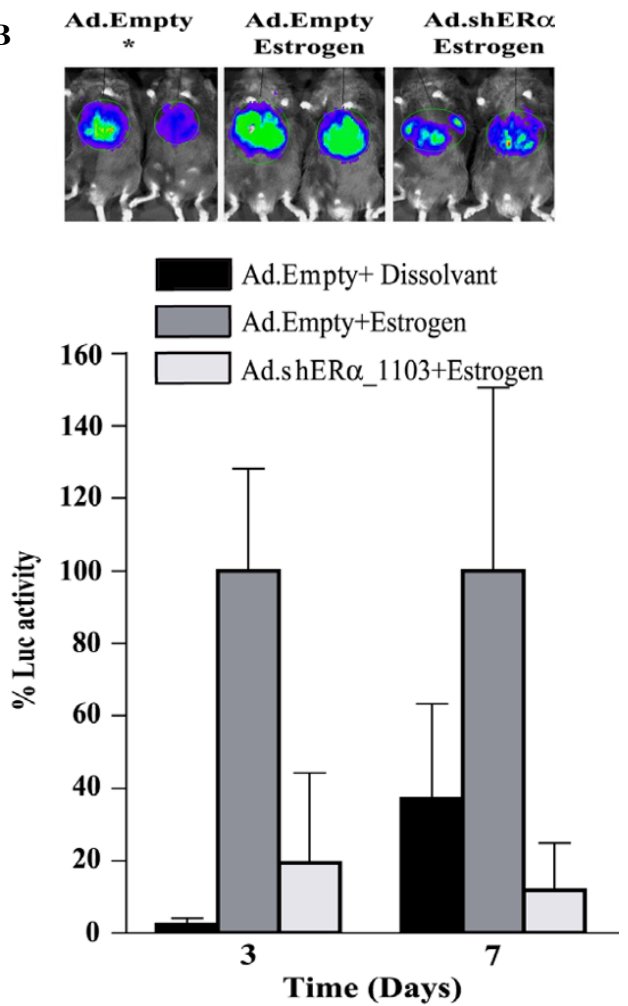

C

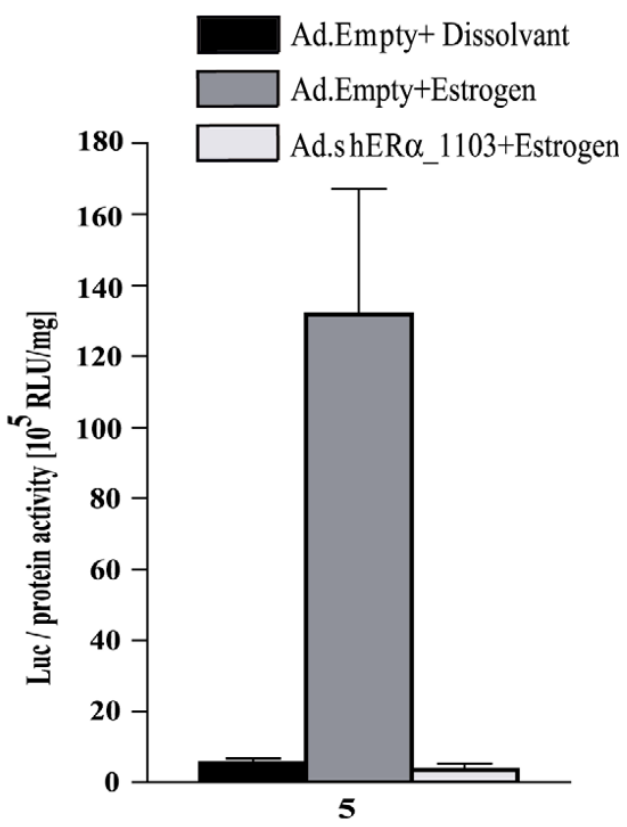

Time (Days)

\section{Figure 4}

Hepatic ER $\alpha$ activity. (A) Male wt/ C57BI/6 mice, pre injected with $5 \times 10^{8}$ pfu Ad.LacZ, were injected with $8 \times 10^{8}$ pfu Ad.ERELuc. Five days later, the recipients were treated for 6 hours with increasing amounts of estrogen $(0-50 \mu g / \mathrm{kg}, \mathrm{s} . \mathrm{c})$. Then, the mice were sacrificed, and the livers were processed for luciferase assays. Luciferase activity is expressed as relative luciferase units (RLU) per $\mathrm{mg}$ total liver protein. (B) Male C57BI/6 mice $(n=5)$ were injected with Ad.ERE-Luc $\left(5 \times 10^{8}\right.$ pfu) plus Ad.Empty or Ad.shER $\alpha \_I I 03\left(3 \times 10^{9} \mathrm{pfu}\right)$. Three or seven days post-infection, the mice were injected with $5 \mu \mathrm{g} / \mathrm{kg}$ estrogen. The (inset) photo shows the result of optical imaging of the bioluminescence at day three, the bar-diagram is a quantitative representation of hepatic luciferase activity at day three or day seven. (C) Male C57BI/6 mice $(n=5)$ were co-injected with Ad.ERELuc $\left(5 \times 10^{8} \mathrm{pfu}\right)+$ Ad.Empty or Ad.shER $\alpha \_I 103\left(3 \times 10^{9} \mathrm{pfu}\right)$. Five days later, the mice received 0 or $5 \mu \mathrm{g} / \mathrm{kg}$ estrogen. After 6 hours, the animals were sacrificed, and hepatic luciferase activity was determined. Luciferase activity is expressed as relative luciferase units (RLU) per $\mathrm{mg}$ total liver protein. Data represented as mean $\pm \mathrm{SD}$. 
with the murine ER $\beta$ sequence totals five, making it unlikely that the shER $\alpha \_1395$ construct would affect expression of ER $\beta$. Similarly, the shER $\alpha \_1103$ construct has three mismatches with the human ER $\alpha$ and nine mismatches with murine ER $\beta$, making it unlikely that the shER $\alpha$ 1103 construct would interfere with either of them. A single mismatch in the shER $\alpha \_1395$ sequence did render the construct ineffective in down-regulating murine ER $\alpha$ (data not shown). Thus, the two independent shER $\alpha$ constructs described here are exquisitely suited to demonstrate that a specific effect is mediated by downregulation of ER $\alpha$ expression and not by down-regulation of a related sequence.

A key challenge in the application of an shRNA based approach is efficient delivery of the shRNA constructs to target cells in vitro and in vivo. For application of shRNA in vivo, the sh oligopair, driven by H1 RNA polymerase [2] or U6 promoter [6], can be cloned in viral vectors. Here, the Ad vector was chosen as delivery vector, because of the relative ease of generation and amplification. Moreover, the natural tropism of Ad vectors for the liver enables the rapid analysis of the hepatic knock-down phenotype. Since Ad vectors predominantly infect the parenchymal cells $[7,8]$, it is important to note that most abundant hepatic ER $\alpha$ expression was detected in parenchymal cells while ER $\alpha$ expression was barely detected in hepatic endothelial cells or kupffer cells (data not shown). This supported the rationale for application of shER $\alpha$ Ad vectors in vivo. Another interesting observation was that upon administration of $4 \times 10^{9} \mathrm{pfu}$ Ad.shER $\alpha$, an $85 \%$ reduction of ER $\alpha$ mRNA levels was obtained (Fig. 5), whereas co-injection of $3 \times 10^{9} \mathrm{pfu}$ Ad.shER $\alpha \_1103$ with $5 \times 10^{8}$ pfu Ad.ERE-Luc resulted in an almost complete absence of luciferase activity (Fig. 4C). The ratio of Ad.ERE-Luc versus Ad.shER $\alpha \_1103$ (1:6) should ensure that all cells that were transduced by Ad.ERE-Luc also received Ad.shER $\alpha \_1103$. Thus, the remainder of ER $\alpha$ expression determined by real-time PCR likely reflects ER $\alpha$ expression in non-parenchymal and non-infected cells.

Thus far, relative few reports describe the application of Ad vectors as delivery system for RNAi in vitro [9-12]. Similarly, relative few studies on effective RNA interference in vivo using Ad mediated gene transfer have been reported [13-15]. One potential explanation for this relative paucity in the application of Ad mediated gene transfer for shRNA expression constructs could lie in the recent observations of Lu and Cullen [16], that VA1 non-coding RNA, expressed by wild type adenovirus is a potent inhibitor of RNA interference. However, replication-incompetent adenovirus vectors such as the vectors used in our study have been reported to express low levels of VA1 [16]. Moreover, in our hands the effect of the pSUPER shRNA construct shER $\alpha \_1935$ on reduction of ER $\alpha$ activity in vitro was not affected by super-infection with the Ad.empty vector (data not shown). Thus, the Ad vectors applied in this study seem to have no or a minor inhibitory effect on the RNAi response in vitro and in vivo. Whether this effect is also insert specific and/or depends on the particular target gene remains to be investigated.

The strongest evidence for efficient reduction of endogenous hepatic ER $\alpha$ RNA levels in vivo was obtained by coinjection of Ad.ERE-luc and advanced non-invasive in vivo optical imaging. Administration of Ad.ERE-luc led to readily detectable levels of luciferase activity from day 3 up to day 7 and disappeared at day 10 (data not shown). In agreement with this, the Ad.shERa mediated knockdown effect was present at day three, five, and seven postinjection (Fig 4B). This represents a 4 to 5 -day window of expression to determine the phenotypic effects of hepatic shRNA-mediated reduction of mRNA levels.

\section{Conclusion}

We have shown significant repression of hepatic ER $\alpha$ activity in mice utilizing Ad.shER $\alpha$ vectors. In addition, using advanced non-invasive optical imaging technology, the dynamics of the knock-down effect in vivo have been demonstrated. Thus, our data confirm that application of shRNA represents a powerful tool for targeted gene silencing. We conclude that Ad-mediated delivery of shER $\alpha$ constructs represents an elegant tool to gain more insight in the role of the hepatic ER $\alpha$.

\section{Methods Plasmids}

Two oligonucleotide pairs (mER $\alpha \_1395:$ 5'gatccccgctcctgtttgctcctaacttcaagagagttaggagcaaacaggagcttttggaaa-3' and 5'agcttttccaaaaagctcctgtttgctcctaactctcttgaagttaggagcaaacaggagcggg-3', mER $\alpha$ 1103: 5'-gatccccgaatagccctgccttgtcc ttcaagagaggacaaggcagggctattc tttttggaaa-3' and 5'-agc ttttccaaaaagaatagccctgccttgtcctctcttgaaggacaaggcagggctattcggg) were ordered (Eurogentec, United kingdom). The bold nucleotides correspond to nucleotides 1395-1418 and 1103-1120 of the mRNA mER $\alpha$ sequence (GenBank accession number NM 007956). The underlined nucleotides represent a BglII and a HindIII site. These oligo's were annealed and ligated between the BglII and HindIII sites of pSUPER-H1prom [2]. The pSUPER-shER $\alpha$ sequences were verified by restriction and sequence analysis (ABI 3700, LGTC, Leiden).

The H1prom plus or minus shER $\alpha$ were cloned from the pSUPER into the promoter less pAdTrack vector [5] by use of $X b a \mathrm{I}$ and $\mathrm{XhoI}$ restriction sites. The Ad.shER $\alpha$ tandem construct was generated by ligation of H1promshERo_1103 between the NotI and KpnI sites of pTrackH1prom-shERa_1395. 
The (ERE) $)_{3}$ TATA-Luc was cloned from $\mathrm{pGl}_{3}$-basic as a ClaI-blunt/ KpnI fragment in EcoRV- and KpnI- digested promoter less Shuttle vector (pShuttle) (He et al. 250914). The functionality of this construct was verified by transfection. hER $\alpha$ was cloned from pCMV5 (pCMV5$\mathrm{hER} \alpha)[17]$ as a BamHI fragment in the BglII digested pShuttle-CMV vector. The pcDNA3.1-mER $\alpha$ expression vector was provided by Larry Jameson [18] and subcloned as a EcoRI-blunt fragment in the EcoRV digested pShuttle$\mathrm{CMV}$ vector.

\section{Cell culture}

The $\mathrm{MXT}^{+}$(murine breast cancer) cell line was generously provided by Dr. Bernards. H5V (a murine endothelial cell line derived from heart), EOMA (murine hemangiomaderived micro vascular cell line) and MXT cells were maintained in Dulbecco's modified Eagle's medium (DMEM) (Gibco BRL) supplemented with $10 \%$ fetal calf serum, 100 units $/ \mathrm{ml}$ Penicillin, $100 \mu \mathrm{g} / \mathrm{ml}$ Streptomycin and glutamax (Invitrogen) (Complete DMEM). PERC6 cells [19] were maintained in complete DMEM supplemented with $10 \mathrm{mM} \mathrm{MgCl}^{2+}$. For large-scale production of recombinant Ad in PERC6 cells (Crucell, Leiden, he Netherlands), complete DMEM with $2 \%$ horse serum (Gibco) was used.

\section{Luciferase reporter assays}

Transient transfections were performed in triplicate in 12wells plates $\left(1.10^{5}\right.$ cells per well) using Lipofectamine (Invitrogen). The effect of shER $\alpha$ on ER $\alpha$ mediated transcription regulation was determined by co-transfecting the cells with $100 \mathrm{ng}$ of reporter construct (ERE) ${ }_{3}$ TATALUC and $500 \mathrm{ng}$ expression vector pSUPER-shER $\alpha$ or an empty pSUPER control vector together with $100 \mathrm{ng}$ pCMV-LacZ. After 24 hours, the cells were stimulated with complete DMEM containing $10^{-9} \mathrm{M}$ Estrogen for an additional 24 hours. The cells were lysed with reporter lyses buffer (Promega) and after centrifugation of $2 \mathrm{~min}$, supernatant was used for determining $\beta$-galactosidase normalized luciferase activity by adding $100 \mu \mathrm{l}$ luciferyl-CoA (Promega) to $20 \mu \mathrm{l}$ of cell extract in a monolight luminometer (BD Biosciences). $\beta$-galactosidase was measured in a 96-well microtiter plate using the $\beta$-Galactosidase Enzyme Assay System in reporter lyses buffer (Promega). Absorbance at $450 \mathrm{~nm}$ was determined in a microplate reader. Luciferase activities were normalized for transfection efficiency with the $\beta$-galactosidase activity and expressed as a percentage relative to expression levels induced by endogenous estrogen receptor (ER). Expression of endogenous $E R \alpha$ in those cells was verified by real time PCR.

\section{Western blot analysis}

Immunoblotting procedures were as described previously [20]. H5V cells seeded in triplicate in 12-wells plate were co-transfected with $20 \mathrm{ng}$ pCMV-mER $\alpha$ and $500 \mathrm{ng}$ expression vector pSUPER-shER $\alpha$ or an empty pSUPER control vector as described above. 28 hours post-transfection, the cells were lysed in $200 \mu$ l of RIPA buffer $(1 \%$ NP40, 0.5\% DOC, $0.1 \%$ SDS, $50 \mathrm{mM}$ Tris $\mathrm{pH} 8.0,150$ $\mathrm{mM} \mathrm{NaCl}, 2.5 \mathrm{mM}$ EDTA) containing protease inhibitor ( $40 \mathrm{ul} / \mathrm{ml}$, Roche). Extracts were cleared by centrifugation $\left(4^{\circ} \mathrm{C}, 14000 \mathrm{~g}, 5 \mathrm{~min}\right)$, and protein content was determined using the BCA kit (Pierce). Protein samples were denaturated $\left(5 \mathrm{~min}, 90^{\circ} \mathrm{C}\right.$ ) and separated on SDS/PAGE by use of $8 \%$ gradient gels and were transferred to polyvinylidene difluoride (PVDF) membranes (Millipore, Germany). Blots were stained with Ponceau S before blocking to verify equal loading and appropriate protein transfer. Membranes were blocked for $90 \mathrm{~min}$ in PBS, pH 7.4, containing $0.05 \%$ Tween 20 and $10 \%$ milk powder. Thereafter, membranes were incubated for $16 \mathrm{~h}$ at $4{ }^{\circ} \mathrm{C}$ with ab MC20, 1:1000 (mER $\alpha$ rabbit polyclonal antibody, Santa Cruz Biotechnology, CA). After extensive washing with blocking buffer without milk powder or BSA, membranes were incubated for $2 \mathrm{~h}$ with horseradish peroxidase-conjugated goat anti-rabbit IgG, 1:5000 (Promega). Membranes were again extensively washed and bound peroxidase conjugates were visualized by enhanced chemiluminescence (ECL, Amersham) on a LumiImager workstation. Additionally, filters were stripped by a 30 min incubation in $100 \mathrm{mM} \beta$-mercaptoethanol, $2 \%$ SDS, $62.5 \mathrm{mM}$ Tris- $\mathrm{HCl} \mathrm{pH} 6.8$ at $50^{\circ} \mathrm{C}$, to proceed with the whole procedure as described above. However, now membranes were incubated for $16 \mathrm{~h}$ at $4^{\circ} \mathrm{C}$ with p-38 ab, 1:1000 (N-20, cs-728, rabbit polyclonal antibody, Santa Cruz Biotechnology, CA). Immunoblots were quantified using LUMIANALYST software on a Lumilmager (Boehringer-Mannheim).

\section{Adenoviral vectors}

Recombinant adenoviral plasmids were generated by homologous recombination of pAdtrack or pShuttle vectors with pAdEasy1 in BJ5183 cells as described previously [5]. Correct clones were propagated in DH5 $\alpha$ cells (Life Technologies). For the generation of the Ad.shER $\alpha$ vectors, Ad.Empty and Ad.ERE-Luc, PERC6 cells were transfected with $4 \mu \mathrm{g}$ Pac-I-linearized adenoviral construct using LipofectAMINE PLUS (Life Technologies). After 16 hours transfection medium was replaced by growth medium. Transfected cells were harvested at day seven post-transfection and after three freeze-thaw cycles the lysate was used for large-scale production of Ad vectors in PERC6 cells. Virus was purified by double $\mathrm{CsCl}$ centrifugation and subsequently dialysed as described previously [21]. Final yields as assessed by plaque assays on 911 cells were approximately $2 \times 10^{10}$ plaque forming units (pfu)/ $\mathrm{ml}$. The control virus (Ad.Empty) carries the green fluorescent protein (GFP) under control of cytomegalovirus promoter (CMV) and contained the H1prom. 
Ad.shER $\alpha \_1395$ and Ad.shER $\alpha \_1103$ carry GFP under control of CMV and shER $\alpha \_1395$ or shER $\alpha \_1103$ under control of H1prom. Ad. shER $\alpha$ tandem carries both shER $\alpha \_1395$ and shER $\alpha \_1103$ under control of their own H1prom. Ad.ERE-Luc does not contain CMV-GFP and its functionality was verified in vitro and in vivo.

\section{Infection cells}

24 hours before transfection, $1.10^{5}$ cells per well were seeded into12 wells-plate. Cells were transiently transfected by use of lipofectamine with a total of $450 \mathrm{ng}$ of DNA per well (150 ng of reporter plasmid (ERE) ${ }_{3}$ TATALUC and $300 \mathrm{ng}$ pCMV-LacZ). After 4 hours cells were infected with either Ad.shER $\alpha$ or control Ad.Empty (MOI 5.000 ). Additionally, they received $10^{-9} \mathrm{M}$ estrogen for 24 hours. Cells were lysed in $300 \mu$ l reporter lyses buffer. $\beta$ galactosidase and luciferase activity was determined as described above.

\section{Animals and Ad Injection}

The Ethics Committee for Animal Experiments of the Leiden University approved all animal work and the experimental protocols complied with the national guidelines for use of experimental animals. Male C57Bl/6JIco (Charles river, The Netherlands) were given a standard $\mathrm{m}$ diet Chow (Hope Farms, Woerden, NL) and housed under standard conditions in conventional cages with free access to water and food.

Recombinant Ad, with a maximum of $4 \times 10^{9}$ pfu in 200 $\mu \mathrm{l}$ of PBS, were administered by injection into the tail vein of mice at the age of 14 weeks. Within five days post-infusion, mice were sacrificed; liver pieces were removed and immediately deep-frozen in liquid nitrogen and stored at $-80^{\circ} \mathrm{C}$.

\section{Pharmacological treatment}

The experiment was carried out in 12-wks old C57BL/6 male mice. To prevent sequestration of low doses of Ad.ERE-Luc by liver Kupffer cells, mice were pre-injected with Ad.LacZ $\left(5 \times 10^{8} \mathrm{pfu}\right) 4$ hours before administration of $8 \times 10^{8}$ pfu Ad.ERE-Luc. $17 \beta$-estradiol (Sigma, E8875) was dissolved in sesame oil (Sigma). In the dose-response experiment, five days post-injection of Ad.ERE-Luc, 0, 5, 25 and $50 \mu \mathrm{g} / \mathrm{kg} 17 \beta$-estradiol was injected for 6 hours. Then liver pieces were rapidly dissected and immediately deep-frozen in liquid nitrogen and stored at $-80^{\circ} \mathrm{C}$ for further analysis.

\section{Bioluminescent reporter imaging}

The experiment was carried out in 12 wks old C57BL/6 male mice co-injected with Ad.ERELuc $\left(5 \times 10^{8} \mathrm{pfu}\right)$ plus either Ad.Empty or Ad.shER $\alpha\left(3 \times 10^{9} \mathrm{pfu}\right)$. Bioluminescent signals (BLS) were performed at time 0 and at several days after 6 and 24 hours s.c injections of $5 \mu \mathrm{g} / \mathrm{kg} 17 \beta$ - estradiol with the Xenogen IVIS imaging system (IVIS 100). The living mice were intraperitoneal (ip) injected with the luciferase substrate, luciferin, at a dose of 150 $\mathrm{mg} / \mathrm{kg}$ body weight approximately 5 minutes before imaging. The mice were anaesthetized with isoflurane/oxygen and placed on the imaging stage. Total photon emission of each animal was acquired for 1 minute. Captured images were then quantified by using the Living Image software (Xenogen Corp, Almeda, CA) and the IGOR software (WaveMetrics Corp, Lake Oswego, OR). BLS from the region of interest (ROI) was expressed using the pseudo colour scale (Red most intense and Blue least intense luminescence) and the data were presented as the cumulative photon counts collected within each ROI. Because layers of tissue may limit photon emission from inner organs, the experiment was repeated. Of these mice the livers were rapidly dissected at day 5, 6 hours after $17 \beta$-estradiol administration, verifying the results from the bioluminescent reporter imaging by determining the luciferase activity in liver lysates

\section{Luciferase enzymatic assay}

The liver extracts were prepared by homogenisation with the minibead beater in reporter lyses buffer (Promega), two cycles of freeze-thawing and $2 \mathrm{~min}$. of centrifugation at maximum speed. Supernatants were used for determining protein-normalized luciferase activity by adding 100 $\mu \mathrm{l}$ luciferyl-CoA (Promega) to $20 \mu \mathrm{l}$ of liver extract in a monolight luminometer (BD Biosciences). Protein content was measured in a 96-well microtiter plate using the BCA protein assay kit (Pierce). Absorbance at $562 \mathrm{~nm}$ was determined in a microplate reader.

\section{Real time quantitative PCR analysis}

Total RNA was extracted from liver using TRIzol reagent (Life technologies). Purified RNA was treated with RQ1 RNase-free DNase (Promega, 1 units $/ 2 \mu \mathrm{g}$ of total RNA) and reverse transcribed with SuperScript II Reverse Transcriptase (Invitrogen) according to the manufacturer's protocol. Quantitative gene expression analysis was performed on an ABI prism7700 Sequence Detection System (Applied Biosystems) using SYBR Green as described earlier (Hoekstra et al. 25448-53). PCR primer sets (Cyclophilline, Fw: AAAAGGAAGACGACGGAGCC Rev: TCGGAGCGCAATATGAAGGT and mER $\alpha$, Fw: CTAGCAGATAGGGAGCTGGTTCA, Rev: GGAGATTCAAGTCCCCAAAGC) were designed via Primer Express 1.7 software with the manufacturer's default settings (Applied Biosystems) and were validated for amplification efficiency. The absence of genomic DNA contamination in the RNA preparations was confirmed in a separate PCR reaction on total RNA samples that were not reverse transcribed. Cyclophilline was used as a control. 
Data Analysis - The significance of differences in relative gene expression numbers $\left.\mathrm{C}_{\mathrm{t}}\left(\mathrm{C}_{\mathrm{t}((\mathrm{Cyclo})}\right)^{\left.-\mathrm{C}_{\mathrm{t}} \text { (target gene }\right)}\right)$ measured by real time quantitative PCR was calculated using a two-tailed Student's $t$ test. Probability values less than 0.05 were considered significant.

\section{Abbreviations}

Ad5, Human Ad serotype 5; Ad.shER $\alpha$, Ad mediated expression of shER $\alpha$; Ad.ERE-Luc, Ad mediated expression of ERE-Luc; ArKO, Aromatase knockout; CCD, Charged coupled device; DMEM, Dulbecco's modified Eagle's medium; ER, Estrogen Receptor; ERE, Estrogen Responsive Element; GFP, Green Fluorescent Protein; Ip, Intraperitoneal; Luc, Luciferase; Pfu, Plaque forming units; S.c, Subcutaneous; siRNA, small interfering RNA; shRNA, short hairpin RNA; shER $\alpha$, shRNA specific for mouse ER $\alpha$; $\mathrm{Wt}$, wild type

\section{Authors' contributions}

Y.K carried out the studies described in this paper and drafted the manuscript. F.F participated in the concept of designing shER $\alpha$. I.Q and C.L. contributed to the imaging experiments shown in Fig 4B. K.WvD participated in the design and coordination of this study and provided expert input for writing the manuscript. All authors read and approved the final manuscript.

\section{Acknowledgements}

We would like to thank Andre van der Zee for his technical assistance. We thank Prof. R.R Frants and Prof. L.M Havekes for their intellectual input. This work was performed in the framework of the Leiden Center for Cardiovascular Research LUMC-TNO and supported by grants from the Dutch Organization for Scientific Research (NWO 902-26-220), Dutch Heart Foundation (NHS 200I-I4I) and the Center of Medical Systems Biology (CMSB) established by the Netherlands Genomics Initiative/Netherlands Organisation for Scientific Research (NGI/NWO).

\section{References}

I. Elbashir SM, Harborth J, Lendeckel W, Yalcin A, Weber K, Tuschl T: Duplexes of 2 I-nucleotide RNAs mediate RNA interference in cultured mammalian cells. Nature 200I, 41 I:494-498.

2. Brummelkamp TR, Bernards R, Agami R: A system for stable expression of short interfering RNAs in mammalian cells. Science 2002, 296:550-553.

3. Shen C, Reske SN: Adenovirus-delivered siRNA. Methods Mol Biol 2004, 252:523-532.

4. Xia H, Mao Q, Paulson HL, Davidson BL: siRNA-mediated gene silencing in vitro and in vivo. Nat Biotechnol 2002, 20:1006-1010.

5. He TC, Zhou S, da Costa LT, Yu J, Kinzler KW, Vogelstein B: A simplified system for generating recombinant adenoviruses. Proc Natl Acad Sci U S A 1998, 95:2509-25।4.

6. Zheng L, Liu J, Batalov S, Zhou D, Orth A, Ding S, Schultz PG: An approach to genomewide screens of expressed small interfering RNAs in mammalian cells. Proc Natl Acad Sci U S A 2004, I 0 I: I35-140.

7. Guo ZS, Wang LH, Eisensmith RC, Woo SL: Evaluation of promoter strength for hepatic gene expression in vivo following adenovirus-mediated gene transfer. Gene Ther 1996, 3:802-810.

8. Li Q, Kay MA, Finegold M, Stratford-Perricaudet LD, Woo SL: Assessment of recombinant adenoviral vectors for hepatic gene therapy. Hum Gene Ther 1993, 4:403-409.

9. Arts GJ, Langemeijer E, Tissingh R, Ma L, Pavliska H, Dokic K, Dooijes R, Mesic E, Clasen R, Michiels F, van der SJ, Lambrecht M, Herman S,
Brys R, Thys K, Hoffmann M, Tomme P, van Es H: Adenoviral vectors expressing siRNAs for discovery and validation of gene function. Genome Res 2003, I3:2325-2332.

10. Bain JR, Schisler JC, Takeuchi K, Newgard CB, Becker TC: An adenovirus vector for efficient RNA interference-mediated suppression of target genes in insulinoma cells and pancreatic islets of langerhans. Diabetes 2004, 53:2190-2194.

II. Shen C, Buck AK, Liu X, Winkler M, Reske SN: Gene silencing by adenovirus-delivered siRNA. FEBS Lett 2003, 539: I I I- I |4.

12. Zhao LJ, Jian $H$, Zhu H: Specific gene inhibition by adenovirusmediated expression of small interfering RNA. Gene 2003, 316:|37-|4|.

13. Huang A, Chen Y, Wang X, Zhao S, Su N, White DW: Functional silencing of hepatic microsomal glucose-6-phosphatase gene expression in vivo by adenovirus-mediated delivery of short hairpin RNA. FEBS Lett 2004, 558:69-73.

14. Lin J, Yang R, Tarr PT, Wu PH, Handschin C, Li S, Yang W, Pei L, Uldry M, Tontonoz P, Newgard CB, Spiegelman BM: Hyperlipidemic effects of dietary saturated fats mediated through PGC I beta coactivation of SREBP. Cell 2005, I 20:26 I-273.

15. Uchida H, Tanaka T, Sasaki K, Kato K, Dehari H, Ito Y, Kobune M, Miyagishi M, Taira K, Tahara H, Hamada $\mathrm{H}$ : Adenovirus-mediated transfer of siRNA against survivin induced apoptosis and attenuated tumor cell growth in vitro and in vivo. Mol Ther 2004, 10:162-171.

16. Lu S, Cullen BR: Adenovirus VAI noncoding RNA can inhibit small interfering RNA and MicroRNA biogenesis. J Virol 2004, 78: | 2868- | 2876 .

17. Montano MM, Muller V, Trobaugh A, Katzenellenbogen BS: The carboxy-terminal $F$ domain of the human estrogen receptor: role in the transcriptional activity of the receptor and the effectiveness of antiestrogens as estrogen antagonists. Mol Endocrinol 1995, 9:814-825.

18. Jakacka M, Ito M, Weiss J, Chien PY, Gehm BD, Jameson JL: Estrogen receptor binding to DNA is not required for its activity through the nonclassical API pathway. I Biol Chem 200I, 276: |36|5-|362|.

19. Fallaux FJ, Bout A, van VI, van den Wollenberg DJ, Hehir KM, Keegan J, Auger C, Cramer SJ, van Ormondt H, van der Eb AJ, Valerio D, Hoeben RC: New helper cells and matched early region Ideleted adenovirus vectors prevent generation of replication-competent adenoviruses. Hum Gene Ther 1998, 9:1909-1917.

20. Ouwens DM, van der Zon GC, Pronk GJ, Bos JL, Moller W, Cheatham B, Kahn CR, Maassen JA: A mutant insulin receptor induces formation of a Shc-growth factor receptor bound protein 2 (Grb2) complex and p2 I ras-GTP without detectable interaction of insulin receptor substrate I (IRSI) with Grb2. Evidence for IRSI-independent p2Iras-GTP formation. I Biol Chem 1994, 269:33 I 16-33122.

21. Fallaux FJ, Kranenburg O, Cramer SJ, Houweling A, van Ormondt $H$, Hoeben RC, van der Eb AJ: Characterization of 9II: a new helper cell line for the titration and propagation of early region I-deleted adenoviral vectors. Hum Gene Ther 1996, 7:215-222.

Publish with Bio Med Central and every scientist can read your work free of charge

"BioMed Central will be the most significant development for disseminating the results of biomedical research in our lifetime. "

Sir Paul Nurse, Cancer Research UK

Your research papers will be:

- available free of charge to the entire biomedical community

- peer reviewed and published immediately upon acceptance

- cited in PubMed and archived on PubMed Central

- yours - you keep the copyright 